\title{
Religion, Science and the Paranormal
}

\author{
J.D. McClymont
}

\begin{abstract}
The article considers the relationship between religion, science and the paranormal. Having distinguished between cultural and critical thinking, the article considers the relationship of both to scholarship and secularism. The article discusses how one should respond to paranormal claims, taking into account S.T. Gill's approach to dealing with smokescreens that paranormal claimants use when confronted. From another point of view, the article looks at the approach to claims of private revelation proposed by the Catholic theologian Adolphe Tanquerey, and evaluates the Humean approach to miracles. The article adopts a middle position between two extremes. On the one hand, the philosophical stance that there should be no blanket exclusion of scepticism for miraculous, supernatural, paranormal or magical claims. On the other hand, the Humean stance that neither should the possibility of the miraculous be ruled out by prior prejudice. Through a dialectical philosophical discourse that often gets into the second person singular to bring the discourse closer to the reader, this paper argues that evidence should speak for itself, without prejudice having any influence.
\end{abstract}

Keywords: religion, science, paranormal, miracles

\section{Introduction}

This article shall consider the relationship between religion, science, scepticism and the paranormal, and shall look at some approaches to miracles and the paranormal, including a secular/Humean approach and the approach of Gill (1991) in the Skeptical Enquirer. In Africa, many people believe in the powers attributed to ngangas (herbalists or witchdoctors) and in the miraculous 
claims of Pentecostal religious teachers. In addition, even in Zimbabwe, one can find literature associated with the New Age movement, a new religious movement associated with the occult (cf. Steyn 1994: 304ff, 308). The question of the relationship of reason with religion and magic ${ }^{1}$ is therefore a relevant one for people living in Africa. What should be the attitude of a rational person to religious and/or magical claims? To start the discussion we may begin by describing two kinds of thought below ${ }^{2}$.

\section{Cultural and Critical Thinking}

The first form of thought may be called cultural thinking. It consists of taking one's fundamental positions or views of life from the surrounding culture, or from an authoritative source, in an uncritical fashion, accepting such views as, so to speak, part of the air one breathes. It is in this way that young children learn many things from their parents. Adults who feel out of their depth in certain areas of life and take the word of eminent authorities or experts may adopt it.

The second form of thought may be called critical thinking. It involves the adoption of fundamental principles and of argued positions based on rationality, using starting points admitting of an objective defence in terms of experience and reason. It is a more adult form of thinking than cultural thinking and can be used to criticize cultural tradition on the basis of experience and reason.

Neither form of thought is inherently invalid, but the former is less mature a form of reasoning than the latter. Thus, it is acceptable to make a personal decision to disbelieve in goblins, simply because you were brought up in a culture that disbelieves in goblins and you have seen no reason to change your mind so far. On the other hand, if you were writing a thesis on some scientific question, you might adopt a more complex form of argument-

${ }^{1}$ I regard magic and the occult as a form of religion in the broad sense. Both of these fit Kruger's (1985: 6) definition of religion as an experience of radical transcending with a view to cosmic orienting. My own definition of religion is a modification of Kruger's, whereby religion is an orientation to what transcends ordinary experience, whereby one's entire life is ordered.

2 The distinction of cultural and critical thinking may owe something to Horton's (1995) discussion of African traditional thought and Western science. 
tation, looking at the evidence for and against your position. To the extent that your evidence was based on experience and reason, it would amount to critical thinking.

\section{Cultural Thinking, Scholarship and Secularism}

Is it critical thinking to quote a literary source, of the kind that is found in bibliographies? Here we have a paradox. If you simply cite a source uncritically, then you are thinking culturally. You are trusting the source like a baby trusts their mother. This may be valid in areas where the source is your only source of information and there is no good reason to doubt it so far. A transition to critical thinking is made when the credibility of the source is rationally examined and/or defended, so that the idea that the source is competent or veracious, if adopted, has a rationale, rather than being a default position.

Yet this puts us in a curious position. How often are scholarly sources in a bibliography given this sort of scrutiny? To assume the truth of a source uncritically is cultural thinking, not critical thinking, even if your 'source' is recently published scholarship generally (McClymont 2014: 2).

A person who accepts an idea uncritically may be right, or may be wrong, but is not in either case exercising critical reason. The term 'reason' is something requiring interrogation. It could refer to the actual use of the understanding in accepting self-evident logical truth or arguing from evident premises. That is how the term has mostly been used in this article so far.

On the other hand, a person could use the word 'reason' to refer to cultural ideas of what is sane or sensible. This use of the word 'reason' is deceptive; it can be applied to ideas that have not been reached rationally, yet in such a way that the prestige attaching to ideas that are reached rationally is effectively hijacked.

It is sometimes said that religion is based on faith, while a secularist may claim their ideas are based on reason (Feser 2008: 3). It is true that religious belief is often uncritically imbibed from a specific culture and takes the form of what I have called cultural thinking. It is wrong, however, to think that religion cannot be a matter of reason. It is possible to propose rational grounds for belief in God, in the immortality of the soul, the resurrection of Jesus Christ, and even the idea that the Catholic Church is the true church of Christ (Sheehan 1937: 17ff, 56, 98ff, 141ff). 


\section{Magic}

When it comes to magic, it is certainly the case that many believe in it for cultural reasons. Yet it is possible for disbelief in magic to be held for cultural reasons also. If one does not hold a belief in n'angas it may be asked: why not? Is such disbelief held on the basis of a general Westernized cultural sense that belief in witchdoctors is irrational and superstitious, which seems so obvious to you that you do not question it? Is it part of the modern air you breathe rather than something you have thought through yourself? If so, then you may be engaging in cultural thinking, and may be vulnerable to the criticism that your ideas are just uncritically held Western cultural beliefs pitted against uncritically held African cultural beliefs.

This is not to say the n'angas are right, but in order to make the issue of the works n'angas that many Westerners may regard as magic, a truly rational debate rather than a clash of cultural ideologies or prejudices, we need a critical framework for evaluating magical claims.

\section{Strategies for Confronting Paranormal Claims}

The first requirement for a critical framework for thinking about magic is that there should be no prejudice for or against magic. We are to have no prejudice in favour of magic or the paranormal. At the same time, we also should have no prejudice against the paranormal. Prejudice, in the sense of the prejudging of an issue without good reason, should have no place in rational thought.

The Committee for the Scientific Investigation of the Claims of the Paranormal (CSICOP), according to the description of its activities given on the back cover of the Skeptical Inquirer magazine (CSICOP 1991), 'does not reject claims on a priori grounds, antecedent to inquiry, but rather examines them objectively and carefully'. Yet a cursory examination of this magazine reveals a generally sceptical attitude to paranormal claims. Thus, a sceptical approach to magic and the paranormal need not require a priori rejection of the possibility. How, therefore, should the paranormal be approached?

Gill (1991: 271) insists that in confronting paranormal claimants the basic principles are that the burden of proof is on the claimant, and extraordinary claims require extraordinary proof. We may comment here that the idea that 'the burden of proof is on the claimant' is probably understood by Gill not as a prejudice but a common-sense presumption in favour of the normal working of nature. We presume in everyday life that the laws of nature 
will continue to work; we do not expect our relatives to rise from the dead on a daily basis, for example, nor do we expect elephants to fly; and therefore if somebody says he saw an elephant fly, it is for the claimant to prove that the elephant flew. It is not for us to prove that the elephant did not fly, because the non-flight of elephants is the ordinary default common-sense position. To dislodge that position, some impressive evidence would be needed. That is how I would try to explain Gill's view here.

\section{Gill on Paranormal Smokescreens and How to Respond to Them}

Gill (1991: 272-273) mentions some 'smokescreens' that paranormal and other claimants will raise when asked for evidence. It should be noted that his article deals not only with strictly paranormal claims, but also with fringe science stuff like UFOs (ibid. 272). These smokescreens, and the strategies he recommends for meeting them (ibid. 272-273), may be summarized as follows:

1) It may be claimed that some truth transcends the need for proof. Gill recommends the following: Ask whether the beliefs of a claimant are his or her religion. If not, then they are subject to rational inquiry. If they are, then you should ask the claimant whether God told them this or that was correct, at which point you can claim that God told YOU just the opposite!

2) It may be claimed that the claimant's teacher was sincere and convinced, and would not lie. Gill replies by indicating that sincerity falls short of proof.

3) The claimant may encourage you not to take his word for anything but offers to teach you to do paranormal things yourself (like travelling outside of the body, psychokinesis ${ }^{3}$, etc.). Gill recommends doing some consumer research and asking for a demonstration of the power concerned.

4) The claimant may accuse you of closed-mindedness. Gill would reply that he himself would be willing to change his mind on the production of

${ }^{3}$ Psychokinesis is the power to move things with your mind alone. Chandler (1988: 180-181) talks of a class that claims to teach people how to make spoons bend using only the power of thought. 
impressive enough evidence, but he would ask the claimant whether it was possible that they might themselves be wrong or have been convinced by inadequate evidence. If a 'No, never' answer were given, Gill would ask who then truly had an open mind here.

5) It may be claimed that the claim cannot be proven wrong. To this Gill poses the question of what the best evidence is in favour of the claim, thereby shifting the debate not to whether the claim can be proven or disproven but whether the evidence in favour of the claim is simply the claimant's word for it, or something better.

6) It may be claimed that science does not know everything. Gill responds that science is not about memorized facts but about finding things out and evaluating evidence. (In support of Gill we may point out that a person who has incomplete factual knowledge may still have valid critical observations to make on an issue.)

7) It may be claimed that the subject-matter of the claim is 'spiritual' like what is found in the Bible. Against this Gill cites biblical verses like Isaiah 2: 6, Deuteronomy 18: 9-12, etc. which are critical of psi-type powers.

8) It may be claimed that studies of the subject-matter of the claim were more advanced in other times and places (e.g. ancient times, or in the East). The question would then arise what evidence convinced people in these times or places.

9) The claimant may say they have themselves made a study of the subjectmatter of the claim. At this point Gill would challenge the claimant to produce the evidence that convinced him or her.

10) The claimant may claim the questioner is not qualified to question the subject-matter of the claim. At this point they may be asked what qualifications are needed here. Gill envisages a situation where a claimant claims they can teach a class to do something paranormal, and would respond by asking why, if a person could learn to do something paranormal, they could not investigate it.

\section{My Comments on Gill's Paranormal Smokescreen Strategies}

A general theme that emerges in Gill's discussion of smokescreens is the use of techniques to get people to reason culturally rather than critically, and the attempt to substitute uncritical or minimally critical acceptance of authority in the place of rational inquiry that might arrive at awkward conclusions. 
In Strategy 1 ('Some truth transcends the need for proof') the attempt is made to get the hearer to accept something using a mode of belief that does not involve proof, as sometimes happens when religious claims are made. It may be observed that Gill's counter-trick, of claiming that God told him the opposite of what God is said to have told a paranormal claimant, is not really ethical. This is because it involves deception; nevertheless, it does reveal that religion cannot do without critical reason, since it is necessary to evaluate contradictory religious claims, and simple assertion of religious authority can be performed with respect to contradictory religious doctrines. In Catholic apologetics an attempt is made to find reasons for believing the claims of the Catholic church rather than other churches (Sheehan 1937: 141ff), and simple appeal to the 'Bible only' as the sole source of faith is deemed unsatisfactory, since contradictory religious positions can appeal alike to the 'Bible only' (ibid. 146-147).

In Strategy 7 ('It's all spiritual, like in the Bible'), there is a similar attempt to get the hearer into the mood of acceptance generally offered in society towards religious teachers. Yet Gill's quotations from scripture reveal that fraudulent forms of religion need to be guarded against, so mere acceptance of an unusual religious message can be a pitfall. According to Gill (1991: 273 ), the biblical authors 'knew a con game when they saw it 3000 years ago'.

In Strategies 2, 8 and 9, there is 'minimally critical' appeal to authority. Strategy 2) appeals to the sincerity and Strategy 9) to the competence of the claimant. It is true that sincerity and competence are relevant to the critical evaluation of authority, but the 'smokescreens' attempt to reduce such inquiry to an elementary and toothless level. Similarly, Strategy 8 ('The matter was studied at a more advanced level at other times and places'), is an appeal to competence, which however may not stand up to searching inquiry.

In Strategy 6 ('Science doesn't know everything'), and Strategy 10 ('You are not competent to question the subject-matter'), there are attempts to discredit the authority of the questioner. It should be noted that questioning the competence of an authority should take into account available data on such competence, which includes whether the authority talks sense or nonsense. This will require giving the authority a fair hearing instead of saying, 'You are not an expert, so shut up.' It is also a mistake to turn a rational query into a debate about authority, for a valid argument or observation remains a valid argument or observation, whether the proposer or observer is an expert or a novice in a particular discipline. You do not have to have a university degree 
in mathematics, or even a high school diploma, in order to say that $2+2=4$. In Strategy 4 ('You are closed minded'), there is another attempt to discredit the authority of the questioner, this time by imputing base motives.

In all of the above, authority is used in such a way as to pit it against reason. This observation does not mean that authority is wrong, but rather that authority should be used in such a way as to allow free play to critical reason. Gill's article was mostly about paranormal claimants in America, but we can apply his strategies to claims made in Africa by traditional healers and even by prophets who claim miraculous powers. It is desirable that a miraculous claim be evaluated using critical reason. A Christian may profess to believe in the whole Bible as the word of God, and may believe as part of his faithcommitment that the miracles of Jesus and Paul really happened; but modern 'prophets' do not necessarily fall under the mantle of Jesus and Paul.

\section{Evaluating Private Revelations}

In fact, it is part of the strategy of the Catholic Church to be critical of claims of private revelation in our day. A modern prophet who wished the Catholic Church to officially view his revelations as worthy of belief would have to run a formidable gauntlet of testing. Tanquerey (1948: 704) recommends that the claimant of a private revelation be tested, and the following should be established, inter alia:

1) Whether the recipient of revelation is well-balanced or affected by neurosis or hysteria.

2) Whether the recipient is possessed of common sense or, on the other hand, has a vivid imagination along with excessive emotionalism.

3) Whether the recipient is educated, and by whom.

4) Whether the recipient's mind is weakened by disease or fasting.

5) Whether the recipient is given to exaggeration.

6) Whether they are self-possessed or passionate.

7) Whether they are solidly virtuous.

8) Whether they are humble.

9) Whether they first communicate their revelations to their spiritual director, instead of the general public. (Rushing to publicize one's revelations immediately, instead of consulting one's spiritual director privately first, is a bad sign. Applying this criterion may expose those 
people who use claims of revelation as a means of self-aggrandizement and self-publicity. The spiritual director may take a more critical attitude to claims of private revelation than the more gullible members of the general public.)

10) Whether the virtues have been practiced to a heroic degree.

Tanquerey (1948: 705-706) advises the rejection of revelations which are contrary to Catholic orthodoxy, obscene, without dignity or ridiculous, and those which enjoin impossible commands. He is suspicious of revelations, which pronounce on theological matters that Catholic theologians freely discussed. Examples include the argument between Thomists and Molinists (Tanquerey 1948: 705-706) and he finally outlines how a revelation may be evaluated according to its fruits (Tanquerey 1948: 706) and indicates the proof which would be afforded by the verification of a miracle and its relation to an apparition (Tanquerey 1948: 707).

This example shows that belief in the reality of the miraculous need not imply credulity about every claim of supernatural revelation. It is not true that 'if you believe in miracles, you will believe in anything' 4 . In fact, the history of religious controversies and disagreements is in fact precisely an account of the refusal of religious persons to believe in just anything. It is fashionable to deplore the bad results of religious disagreements; the World Council of Churches, if I remember correctly, have a slogan to the effect that, 'Action unites, but doctrine divides'. Yet the existence of religious argument may be a sign that the minds of religious believers are awake and functioning, especially when it is a question of systems of theology which take philosophy into account.

I do not therefore regard a blanket prejudice against the supernatural as the sign of a critical mind. To dismiss miracles with a wave of the hand takes much less intellectual effort than to evaluate a claim of private revelation using Tanquerey's criteria.

\section{What About Hume's Argument?}

Having indicated our position that there should be no prejudice for or against

${ }^{4}$ This is a paraphrase of an author, whose name I have now forgotten, who opined that one who believed in the Virgin Birth would believe in anything. 
miracles, we may address a further question: can a true sceptic admit a priori that miracles are possible, however antecedently improbable, or does scepticism require an undefeatable prior rejection of miracles? The discussion of miracles from a philosophical point of view often pays attention to the argument of Hume concerning miracles. Zacharias (1994: 357) summarizes it as saying that a miracle as an exception to the law of nature is by definition based on the lower degree of probability. The wise person, however, will base his views on the higher degree of probability and therefore will always disbelieve in miracles. Zacharias criticizes this argument as circular and points out that it can be argued that the existence of the world is improbable. Should we therefore disbelieve in the existence of the world?

It has been said that Hume's argument is not as circular as has been claimed (Taliaferro 1998: 376) and, as shall be pointed out later, Hume did not rule out the theoretical possibility of a credible miraculous testimony ( $\mathrm{McNabb}$ 1967: 89). We will return to Hume later.

We may recall at this point what science fiction author Stanislaw Lem (1977: 86-87) points out, that the probability of dragons is overwhelming once they have actually come into being. Indeed, natural law is the default presupposition of common sense, which makes defensible a certain scepticism about paranormal claims, as described earlier. Yet perhaps extraordinary proof might be of sufficient force to set aside this presupposition, especially if it takes the form of a direct experience.

\section{Natural and Psychological Law}

The norms of nature include not only physical but psychological norms. Take the case of Jesus' resurrection. It is not normal to rise from the dead, but at the same time, neither is it normal for people to lie about something and stick to it even under the threat of death, with nothing to gain by the deception, nor is it normal for hallucinations to be collective, nor is it normal for there to be a sudden transition from scepticism to faith with no proportionate cause (cf. Strobel 1998: 238, 246-248). Hence, the idea that the apostles were deceivers or deceived in the matter of Jesus' resurrection seems to involve violations of psychological law. It is not a matter of weighing natural versus supernatural hypotheses, but of weighing a supernatural claim against a paranormal claim. Even Hume admitted the theoretical possibility that the testimony favouring a miracle could be plausible if the falsehood of the testimony involved a greater 
miracle (McNabb 1967: 89).

How would we decide between the two? In my view the principle of simplicity, which is a principle one may use to decide between varying hypotheses with equal empirical backing, is an expression of a basic desire to abolish disorder which underlies all human attempts to create order and meaning in life, and amounts to a presumption of order or unity over disorder or disunity. According to the principle of simplicity, we seek the hypothesis or idea which involves the least amount of complication and fits the data (Burnam 1975: 201).

Now a miraculous or paranormal idea may be associated with two kinds of complication: first, the basic complication whereby natural order ceases to apply; secondly, the complication arising from the production of residual disorder as the result of a miracle. The creation of a discrepancy between appearance and reality is one possible form of disorder.

Thus, a healing, being the miraculous production of an orderly condition, would possess only the first kind of complexity; but a miraculous earthquake would possess two kinds of complexity, the basic suspension of natural law plus the mess or destructiveness attendant on the earthquake. A paranormal psychological deception would also have both kinds of complexity - the basic suspension of natural law and the production of disorder in the mind because of this suspension, resulting in a discrepancy between appearance and reality.

We may therefore conceive two kinds of non-normal event, in ascending order of complexity:

1) A constructive miracle, where one of the aforementioned two kinds of complication is present (i.e. there is an event transcending natural law);

2) A destructive paranormal event where two types of complexity exist (i.e. there is an event not fitting in with natural law, and furthermore the event is of a type that creates chaos or destruction. 'Chaos' includes the presence of a discrepancy between appearance and reality).

A worldview favouring the less complex hypothesis will therefore, if it is a matter of choosing between a constructive miracle on the one hand and a destructive and deceptive paranormal event on the other hand, presume in favour of the constructive miracle. 
Now the resurrection of Jesus is a constructive miracle, while the hypothesis of apostolic hallucination or deception in defiance of psychological law involves the disordering or malfunction of the apostles' psyches, in such a way as to cause a discrepancy between appearance and reality, which would be a destructive and deceptive paranormal event. So, in this case, presuming in favour of the constructive miracle would mean presuming in favour of the resurrection of Jesus. Hence, the idea that Jesus rose again takes precedence, even in critical thinking, over the more complex hypothesis of a deception of or by the disciples with paranormal qualities.

Thus, in my view, there can be a rational defence of miracles. There can also be a rational critique of excessive scepticism towards miracles, as I demonstrate in the following section.

\section{The Case Against Tigers: A 'Humean' Proposal}

Hume's idea of natural events is related to uniform experience (McNabb 1967: 89), and his disbelief in miracles is grounded on the idea that 'firm and unalterable' experience of the law is what renders miracles improbable (Flew 1989: 319). I presume that this 'uniform experience' or 'firm and unalterable experience' means the reported experience of the majority that the laws of nature are observed, which is set against the claims of the minority to have experienced miracles (cf. Taliaferro 1998: 376-377). By Humean standards, the fact that the majority of experiences favour the law of nature grants higher probability to the law of nature over miracle (ibid. 376), and the wise person will proportion his belief to the higher probability (Flew 1989: 318). One can expose problems in the Humean position, so understood, by constructing a Humean argument against the existence of tigers, which I employ here as a reductio ad absurdum.

To begin with, let us note that the uniform experience of those who have not experienced tigers is comparable to the uniform experience of those who have not experienced miracles. Just as there is a minority of people who claim to have seen a miracle and a majority who may claim not to have done so, so there is a minority who claim to have seen tigers; yet the vast majority of people in the world have never seen a tiger in the flesh. So, the existence of tigers seems to be against majority experience in the same way as miracles are. The norm that tigers are not seen is based on firm and unalterable experience, and thus, by Humean standards, the case against the sighting of tigers is as firm 
as empirical experience can make it (cf. Flew 1989: 319). However, a tiger is the sort of thing that would be sighted if the empirical and testimonial evidence in its favour were credible. Therefore, by Humean standards, no credible evidence of tigers exists, and therefore tigers almost certainly do not exist.

If an appeal is made to pictures of tigers in books, on TV and in the movies, a Humean response against these seems proposable. For instance, when faced with a reference to miraculous events in a book, or a mysterious photograph, or a piece of footage apparently documenting a paranormal event, a Humean could reply by saying that uniform experience establishes the existence of various forms of deception, lying, hoaxes, fakery, and so on. Thus the possibility of fakery or deception is more firmly evidenced and more empirically grounded than the possibility of miracles. The Humean would therefore reply that the higher probability is that there is fakery or deception in certain books, photographs and film clips, rather than that genuine miracles or paranormal events took place.

Similarly, we may note that a wide range of human experience supports the existence of lots of ways of faking the existence of strange animals, e.g. digital imaging, trick photography, costumes, puppets, toys, Animatronix, false reports, and so on. Most people have experienced a form of fakery of this kind, and some have experienced many of them. So it appears the existence of fakes and deceptions is a truth grounded in majority experience, while the existence of tigers is not. Therefore, it seems the wise person will by Humean standards believe it more likely that a given photo or picture or report of a tiger is a fake or deception than that it is real evidence of a tiger's existence.

Hume stated that if he were to find evidence of Queen Elizabeth dying and rising again he would marvel at the deception involved, but not admit the miracle (Mullin 1979: 12-13). On similar grounds, once one establishes that most people have not seen a tiger, but are acquainted with the existence of some form of falsehood or trickery by which a tiger's existence could be faked, one might imitate Hume's attitude to the putative historically evidenced miracle. One might do so by saying that, in the face of strong-seeming photographic or other evidence of a tiger's existence, one marvelled at the deception involved, but still did not believe in tigers.

By this logic the proper initial response for a Humean, when dragged to a zoo in front of the tiger's cage and asked, 'What is that, then?' is to say, 'My goodness, that is really lifelike. If I were not trained in Humean philoso- 
phy, I would think that was a real tiger. Amazing what these puppeteers can put together these days, isn't it?'

One might try replying that the existence of tigers is not a paranormal event. How would you prove this? For known laws of nature for Hume are established by uniform experience (McNabb 1967: 89). The non-experience of tigers is a widespread uniformity of human experience, for which many empirical testimonies from around the non-Asian world can be adduced in evidence, particularly in Africa, where tiger sightings are, shall we say, difficult to accumulate in great numbers. So, by Humean standards it seems to be a law of nature that tigers cannot be sighted - so that claiming tigers have been sighted in Asia is a paranormal claim which the Humean may by their own standards deem incredible, as they would any other paranormal claim.

Whether or not there is a hidden flaw in my logic, I think the example highlights the need to think carefully about what is meant by the 'natural'. If it means what is normal, in what sense are tigers natural? One might argue there are different norms for different natural conditions, and the natural conditions of parts of Asia (perhaps favouring tigers) are different from those of Africa. How do we know that the natural conditions of Asia favour tigers? The majority experience of humanity is of natural conditions that are not accompanied by tigers, so that by Humean standards (if I interpret Hume's principles correctly) it seems to be, prima facie, a known law of nature that 'conditions of nature do not involve the existence of tigers'. A Humean therefore can claim to be justified in rejecting the claim that natural conditions in Asia involve the existence of tigers, just as he would reject as improbable the claim that natural conditions at the North Pole involve the existence of Santa Claus and his elves.

Common sense, however, says that belief in tigers is reasonable, and that my argument in the preceding paragraphs has got to be a joke of some sort. It would appear that the so-called Humean proposal about tigers given above favours a scepticism of miracles that goes beyond what common sense considers sensible. How does common sense treat tigers?

To ask a related question, how would we know if the norm or expected trend we are used to is more likely to apply in a given case? A presumption that our familiar everyday expected norm for events holds true would be defensible on Occam's razor grounds (violation of a norm being a complication). Therefore, if I live in Africa I normally do not see tigers, and I certainly would not expect to see a tiger in the course of the next few weeks. 
Yet, in the case of the tiger, this presumption in favour of the norm of "no tigers sighted' would be one that fell away in the light of adequate empirical and testimonial evidence of tiger sighting - for example, if I saw a tiger in India, or heard from a reliable witness that tigers had been sighted in India. Otherwise, the common-sense belief that there are tigers could not be defended to one who never normally sees tigers.

Therefore, the presumption in favour of the normally expected pattern of events, according to common sense, holds true until one has sufficient empirical or testimonial evidence that conditions other than those we are used to are in operation. Yet this would allow belief in miracles to be theoretically justified on similar grounds to tiger sightings, i.e. by sufficient 'extraordinary proof' by way of experience and testimony. Just as the presumption against tigers would fall away in the presence of adequate experience or testimony, so a presumption against miracles would fall away in the presence of sufficiently strong evidence. There would be no blanket exclusion of miraculous evidence in advance.

Without the advance exclusion of miracles, or the advance decision to believe in them uncritically, the only fair way to reach judgements about miracles is to give the available evidence, such as it is, a fair and rational examination.

\section{Conclusion}

This article concludes by adopting a middle position between two extremes. On the one hand, there should be no excessive credulity towards miraculous, supernatural, paranormal or magical claims. On the other hand, neither should the possibility of the miraculous be ruled out by prior prejudice. The evidence should speak for itself, without prejudice tipping the scales either way.

\section{References}

Burnam, T. 1975. The Dictionary of Misinformation. London: Futura Publications Ltd.

Chandler, R. 1988. Understanding the New Age. Reading: Word (UK) Ltd.

Committee for the Scientific Investigation of the Claims of the Paranormal 1991. Skeptical Inquirer 15,3. 
CSICOP. See Committee for the Scientific Investigation of the Claims of the Paranormal.

Feser, E. 2008. The Last Superstition. South Bend, Indiana: St. Augustine's Press.

Flew, A. 1989. The Problem of Evidencing the Improbable and the Impossible.

In Zollschan, G.K., J.F. Schumaker \& G.F. Walsh (eds.): Exploring the Paranormal: Perspectives on Belief and Experience. Dorset: Prism Press. Gill, S.T. 1991. Carrying the War into the Never-Never Land of Psi Part I. Skeptical Inquirer 15,3: 269-273.

Horton, R. 1995. African Traditional Thought and Western Science. In Mosley, A.G. (ed.): African Philosophy: Selected Readings. Englewood Cliffs: Prentice-Hall.

Kruger, J.S. 1985. Science of Religion. Pretoria: UNISA. (Only Study Guide for SRB-100-A.)

Lem, S. 1977. The Cyberiad. London: Futura Publications Ltd.

McClymont, J.D. 2014. Religion and Gullibility. Unpublished drafted article. McNabb, D.G.C. 1967. Hume, David. In P. Edwards (ed.): The Encyclopedia of Philosophy: Volume Three. New York: Collier Macmillan Publishers. Mullin, R. 1979. Miracles and Magic: The Miracles and Spells of Saints and Witches. Oxford: Mowbray.

Sheehan, M. 1937. Apologetics and Catholic Doctrine. Part I: Apologetics. Revised Edition. Dublin: M.H. Gill and Son Ltd.

Steyn, C. 1994. Worldviews in Transition: A Study of the New Age Movement in South Africa. Pretoria: UNISA.

Strobel, L. 1998. The Case for Christ. Grand Rapids, Michigan: Zondervan Publishing House.

Taliaferro, J. 1998. Contemporary Philosophy of Religion. Oxford: Blackwell. Tanquerey, A. 1948. The Spiritual Life. Westminster, Maryland: The Newman Bookshop.

Zacharias, R. 1994. Can Man Live Without God? Milton Keynes: Nelson Word Ltd.

J.D. McClymont Department of Philosophy, Ethics and Religion University of Zimbabwe Harare marmack@africaonline.co.zw 